\title{
Effect of Supplementation of Experimental Growth Promoters on Broiler Growth Performance
}

\section{Hrangkhawl $\mathrm{T}^{1}$, Mukhopadhayay $\mathrm{SK}^{1 *}$, Niyogi $\mathrm{D}^{2}$ and Ganguly $\mathrm{S}^{3}$}

${ }^{1}$ Department of Veterinary Pathology, Faculty of Veterinary \& Animal Sciences, West Bengal University of Animal and Fishery Sciences, Kolkata 700 037, WB, India ${ }^{2}$ Department of Veterinary Pathology, College of Veterinary Science \& Animal Husbandry, Narendra Deva University of Agriculture and Technology, Faizabad 224 229, UP, India

${ }^{3}$ AICRP-PHT (ICAR), Department of Fish Processing Technology, Faculty of Fishery Sciences, West Bengal University of Animal and Fishery Sciences, Kolkata 700 094, WB, India

\begin{abstract}
The present study was conducted to study the effect of mannan oligosaccharide and dietary organic acid supplements on body weight of broiler birds. The present investigation showed better growth performance in combination with organic acid salts in terms of body weight. It was found that mean villus length increased significantly $(\mathrm{P}<0.01)$ in the treatment groups rather than the control birds.
\end{abstract}

Keywords: Body weight; Organic acid; Villus length

\section{Introduction}

The present study was conducted on broilers to assess the effect of MOS (Mannan oligosaccharide) and combination of OA (organic acids) and BMD (Bacitracine methylene disalicylate) supplementation on body weight and increase in villi length of different portions of intestine of the broiler birds.

\section{Materials and Methods}

The experiment was conducted on 120 no. day old unisex Vencobb-400 broiler chicks which were divided into six groups consisting of 20 chicks in each group and one group was kept as Control in which the diet was free of acidifier, growth promoter and OA. The feeding and watering troughs were clean and disinfected. The cages were fumigated with formaldehyde and $\mathrm{KMnO}_{4}(2: 1)$ three days prior to arrival of chicks. The cages were kept dry, clean, disinfected and well ventilated during the entire experimental periods. One hundred and twenty day-old Vencobb-400 unsexed/straight broiler chicks after weighing were randomly distributed into six groups, each group having 20 birds were subdivided into four replicates and placed in separate battery brooders. One group was maintained as control and other 5 groups were maintained as treatment groups as given in table 1.

The experimental chicks were maintained under standard conditions of feeding and management.

All the parameters were analyzed by General Linear Model of SPSS (1997) [1]. The results were expressed as mean and pooled SE of mean (SEM), for studying the effects of organic acid on broilers birds. Levels

\begin{tabular}{|c|c|c|c|}
\hline S.No & Group & Mark & Diet \\
\hline 1. & Control & C & $\begin{array}{l}\text { Control diet without acidifier, growth promoter and } \\
\text { organic acids. }\end{array}$ \\
\hline 2. & Treatment-1 & $T_{1}$ & $\begin{array}{l}\text { Diet with Ammonium formate }(0.15 \%)+\text { Calcium } \\
\text { propionate }(0.15 \%)+\text { MOS }(2 \mathrm{gm} / \mathrm{kg})\end{array}$ \\
\hline 3. & Treatment-2 & $\mathrm{T}_{2}$ & $\begin{array}{l}\text { Diet with Formic acid }(0.1 \%)+\text { Propionic acid } \\
(0.1 \%)+\text { Lactic acid }(0.1 \%)\end{array}$ \\
\hline 4. & Treatment-3 & $\mathrm{T}_{3}$ & $\begin{array}{l}\text { Diet with Ammonium formate }(0.15 \%)+\text { Calcium } \\
\text { propionate }(0.15 \%) \text {. }\end{array}$ \\
\hline 5. & Treatment-4 & $\mathrm{T}_{4}$ & $\begin{array}{l}\text { Diet with Lactic acid }(0.1 \%)+\text { Formic acid }(0.1 \%)+ \\
\text { Propionic acid }(0.1 \%)+\text { Activated charcoal }(0.1 \%) \text {. }\end{array}$ \\
\hline 6. & Treatment-5 & $\mathrm{T}_{5}$ & Diet with Bacitracine Methylene disalicylate (BMD) \\
\hline
\end{tabular}

of significance were calculated by Duncan [2], wherever any significant effects were found. Probability of $(\mathrm{P}<0.05)$ was described as significant.

\section{Results and Discussion}

\section{Live body weight}

Average body weight of individual birds of each group were recorded at day 1 and repeated at every 10 days interval till 42 days of age. The highest body weight was observed in group $\mathrm{T}_{1}$ followed by $\mathrm{T}_{3}, \mathrm{~T}_{2}$, and $\mathrm{T}_{4}$ respectively at 4 weeks age. On statistical analysis no significant difference was observed between different treatment groups. At the end of the experimental period significantly higher body weight was recorded in $\mathrm{T}_{1}, \mathrm{~T}_{2}$ and $\mathrm{T}_{3}$ groups compared to the other groups (Table 2).

\begin{tabular}{|c|c|c|c|c|c|c|c|}
\hline & \multicolumn{6}{|c|}{ Treatment Groups } & \multirow[t]{2}{*}{ SEM } \\
\hline & Control & $T_{1}$ & $T_{2}$ & $\mathbf{T}_{3}$ & $T_{4}$ & $T_{5}$ & \\
\hline Day 7 & 129.25 & 137.30 & 127.35 & 133.30 & 130.20 & 129.50 & 3.760 \\
\hline Day 14 & $300.20^{c}$ & $338.75^{a}$ & $306.00 b^{c}$ & $338.10^{\mathrm{a}}$ & $317.70^{b}$ & $302.00^{c}$ & 4.314 \\
\hline Day 21 & $625.25^{b}$ & $675.50^{a}$ & $661.15^{a}$ & $670.35^{a}$ & $666.75^{a}$ & $626.95^{b}$ & 8.134 \\
\hline Day 28 & $940.65^{d}$ & $1045.75^{a}$ & $1015.80^{\text {bc }}$ & $1038.05^{\mathrm{ab}}$ & $1011.90^{c}$ & $946.75^{d}$ & 8.003 \\
\hline Day 35 & $1361.56^{c}$ & $1480.60^{a}$ & $1437.35^{b}$ & $1455.35^{\mathrm{ab}}$ & $1446.58^{\mathrm{ab}}$ & $1370.94^{c}$ & 12.002 \\
\hline Day 42 & $1908.11^{b}$ & $1996.00^{\mathrm{a}}$ & $1989.84^{\mathrm{a}}$ & $1963.95^{\mathrm{a}}$ & $1929.44^{b}$ & $1919.39^{b}$ & 10.319 \\
\hline
\end{tabular}

The birds were weighed after every 10 days and put to test for 42 days, $n=4$ replicate per treated group, each replicate consisted of 5 birds. The body weights of birds were expressed in Mean \pm S.E.

Values bearing at least one common superscript within the row did not differ significantly $(P>0.05)$.

Table 2: Effect of feeding organic acids and mannan oligosaccharide on body weight (in gm) of broiler chicks.

*Corresponding author: Mukhopadhayay SK, Department of Veterinary Pathology, Faculty of Veterinary \& Animal Sciences, West Bengal University of Animal and Fishery Sciences, Kolkata 700 037, WB, India, E-mail: skmpath@gmail.com

Received March 04, 2013; Accepted April 25, 2013; Published April 27, 2013

Citation: Hrangkhawl T, Mukhopadhayay SK, Niyogi D, Ganguly S (2013) Effect of Supplementation of Experimental Growth Promoters on Broiler Growth Performance. Adv Pharmacoepidem Drug Safety 2: 131. doi:10.4172/21671052.1000131

Copyright: (c) 2013 Hrangkhawl T, et al. This is an open-access article distributed under the terms of the Creative Commons Attribution License, which permits unrestricted use, distribution, and reproduction in any medium, provided the original author and source are credited. 
Citation: Hrangkhawl T, Mukhopadhayay SK, Niyogi D, Ganguly S (2013) Effect of Supplementation of Experimental Growth Promoters on Broiler Growth Performance. Adv Pharmacoepidem Drug Safety 2: 131. doi:10.4172/2167-1052.1000131

Page 2 of 2

\begin{tabular}{|l|l|l|l|l|l|l|l|}
\hline $\begin{array}{l}\text { Portion of } \\
\text { intestine }\end{array}$ & Control & $\mathbf{T}_{1}$ & $\mathbf{T}_{2}$ & $\mathbf{T}_{3}$ & $\mathbf{T}_{4}$ & $\mathbf{T}_{5}$ & $\mathbf{S E M}$ \\
\hline Duodenum & $841.5^{\mathrm{e}}$ & $1379.2^{\mathrm{b}}$ & $1477.2^{\mathrm{a}}$ & $1038^{\mathrm{d}}$ & $1357.5^{\mathrm{b}}$ & $1269.5^{\mathrm{c}}$ & 10.783 \\
\hline Jejunum & $786.5^{\mathrm{d}}$ & $1101.5^{\mathrm{b}}$ & $1137.4^{\mathrm{b}}$ & $1014.5^{\mathrm{c}}$ & $1243.9^{\mathrm{a}}$ & $1167.3^{\mathrm{b}}$ & 11.008 \\
\hline lleum & $731.5^{\mathrm{c}}$ & $1025.5^{\mathrm{ab}}$ & $1057.4^{\mathrm{a}}$ & $983.4^{\mathrm{b}}$ & $1082.3^{\mathrm{a}}$ & $1053.2^{\mathrm{a}}$ & 7.979 \\
\hline
\end{tabular}

T: Treatment groups

Values bearing at least one common superscript within the row did not differ significantly $(P>0.05)$.

Table 3: Effect of treatments on the villus length $(\mathrm{mm})$ of different portions of small intestine of broiler chicken at 42 days

It has already been reported that $1 \%$ formic acid or $1.45 \%$ calcium formate did not affect live weight of broiler chicken [3]. The present study also revealed similar result. It was found out that $80 \%$ formic acid and $20 \%$ propionic acid mixture added at $1 \%$ level to broiler chicken ration did not affect live weight [4]. It has also been reported that formic acid and propionic acid mixture (85\% and $15 \%)$ added at $1 \%$ level to the broiler chicken ration in the initial period did not affect weight gain [5]. Reports have also been made about significant increased in body weight gain with the supplementation of $0.5 \%$ lactic acid in drinking water. It was also revealed that increased in body weight with supplementation of lactic acid. The mix of organic acids improved performance of birds [6]. From a dose responsive study, it was concluded (0-0.33\%) that MOS @ $0.11 \%$, maximized weight gain in poultry up to $0-8$ weeks of age. The result was significantly $(\mathrm{P}<0.05)$ better than control group [7]. The same type of effect was found with supplementation of $0.1 \%$ MOS on hybrid Tom's body weight gain [8]. A study was conducted in turkeys supplemented with MOS that MOS may be utilized as a alternative to antibiotic growth promoters to improve turkey performance $[9,10]$

\section{Effect on villus length of different portions of intestine}

Birds were sacrificed from each group at 42 days age and their intestines were taken for slide preparation. Slides were prepared by sectioning and staining the tissues from duodenum, jejunum and ileum [11]. The lengths of the intestinal villi were measured by ocular micrometer under 10X objective of microscope. Average of ten readings was taken from each part of intestine. The reading obtained from ocular micrometer was multiplied by conversion factor derived from stage micrometer. Then the lengths of the intestinal villi were expressed as millimeter $(\mathrm{mm})$ and the lengths were converted into micron $(\mu)$ value. On statistical analysis, significantly $(\mathrm{P}<0.01)$ higher values were observed in treatment groups when compared with control group. Highest villus length in duodenum was observed in $\mathrm{T}_{2}$ then followed by $\mathrm{T}_{1}, \mathrm{~T}_{3}, \mathrm{~T}_{4}$ and $\mathrm{T}_{5}$ and but there was no significant between $\mathrm{T}_{1}$ and T4 (Table 3).

These findings also in lineage with earlier report [9]. Higher villus height in duodenum, jejunum in small intestine was reported with most organic acidifier in diet of broiler [12]. Again it was reported higher villus height in the ileum with the diet based on organic acidifier compared with diet fed without MOS+organic acidifier [13]. It increases villus height and function of secretion, digestion and absorption of nutrients can be appropriately performed by the mucosa [14].

\section{Conclusion}

Supplementation of organic acidifier proves to be a better growth promoter in combination with organic acid salts. It also shows increase in villus height of different parts of small intestine helpful for better

absorption and digestion of feed in the gut. So, organic acidifier reduces the growth of many pathogenic and non-pathogenic intestinal bacteria, decreases intestinal colonization and reduces infections process, ultimately decreasing inflammatory process at the intestinal mucosa.

\section{Acknowledgement}

The authors are thankful to the Vice-Chancellor, West Bengal University of Animal and Fishery Sciences for providing the necessary facilities to carry out the research work.

\section{References}

1. Schultze-Mosgau S, Zielinski T, Lochner J (2004) Web-based, virtual course units as a didactic concept for medical teaching. Med Teach 26: 336-342.

2. Duncan DB (1955) Multiple range and multiple F tests. Biometrics 11: 1-42.

3. Izat AL, Adams MH, Cabel MC, Colberg M, Reiber MA, et al. (1990) Effects of formic acid or calcium formate in feed on performance and microbiological characteristics of broilers. Poult Sci 69: 1876-1882.

4. Kaniawati S, Skinner JT, Waldroup PW, Izat AL, Colberg M (1992) Effects of feeding organic acids to broilers on performance and salmonella Colonization of the caeca and or contamination of the carcass. Poult Sci 71 (Suppl 1): 159.

5. Visek WJ (1978) The mode of growth promotion by antibiotics. J Anim Sci 46 1447-1469.

6. Maiorka A, Santin AME, Borges SA, Opalinski M, Silva AVF (2004) Evaluation of a mix of furamic, lactic, citric and ascorbic acids on starter diets of broilers. Archives of Veterinary Science 9: 31-37.

7. Veeramani P, Selvan ST, Viswanathan K (2003) Effect of acidic and alkaline drinking water on body weight gain and feed efficiency in commercial broiler. Indian J Poult Sci 38: 42-44.

8. Versteegh HAJ, Jongbloed AW (1999) The effect of supplementary lactic acid in diets on the performance of broilers. Institute for Animal science and Health. Branch Runderweg, Lelystad, The Netherlands. ID-DLO Rep No 99.006.

9. Pelicano ERL, Souza PA, Souza HBA, Figueiredo DF, Boiago MM, et al. (2005) Intestinal mucosa development in broiler chicken fed natural growth promoters. Revista Brasileira de Ciencia Avicola 7:4.

10. Podolsky DK (1993) Regulation of intestinal epithelial proliferation: a few answers, many questions. Am J Physiol 264: G179-186.

11. Lillie RD (1965) Histopathological Technique and Practical Histochemistry (3rdedn). p.117. McGraw Hill Book Company. New York.

12. Loddi MM, Nakaghi ISO, Edens F, Tucci FM, Hammas MI, et al. (2004) Mannan-oligosaccharide and organic acids on performance and intestinal morphometric characteristics on broiler chickens. In Proceeding of the 20th Annual Symposium (Suppl.1): 45

13. Savage TF, Zakrzewska EI, Andreasen JR (1997) The effects of feeding mannanoligosaccharide supplemented diet to poultry on performance and the morphology of small intestine. Poult Sci 76 (Suppl. 1): 139

14. lji PA, Tivey DR (1998) Natural and Synthetic oligosachharides in brolier chicken diets, World's Poult Sci 54: 129-143 